\title{
SNAKE RESCUES; A CONSERVATION EFFORT IN KANNUR DISTRICT
}

\author{
Roshnath, R. \\ Malabar Awareness and Rescue Centre for Wildlife, Kannur and Central Univeristy of Kerala, Kasargod. \\ E.mail: roshnath.r@gmail.com
}

\begin{abstract}
Snakes can be found near human habitation because of different reasons of which abundance of prey (rodents) is the major fact. This draws conflict between snakes and humans. Even though snakes are protected with Indian Wildlife Act of 1972, they are generally regarded dangerous creatures to man and whenever spotted deserve no mercy. Hence, recues of the snake is an important factor for conserving the species. Trends in the population of snakes are difficult to monitor due to its sporadic distribution and secretive nature of snakes. Lack of knowledge about the population concerns any conservational plans. This data attempt to document the diversity, population and seasonality of the snakes rescued in Kannur by Rapid response team from October 2011 to October 2014 in Kannur district.
\end{abstract}

A total of 1427 snakes comprising 16 species were rescued in Kannur district of which $65 \%$ were venomous snakes. Indian Spectacled Cobra (Naja naja; 44.1\%) were found to be common venomous snake encountered in the district. Russell's Viper (Daboia russelii; 14.8\%), Common Krait (Bungarus caeruleus; 3.4\%), King Cobra (Ophiophagus Hannah;2.5\%) and few cases of Malabar Pit-Viper (Trimeresurus malabaricus;0.1\%), Common Cat Snake ( Boiga trigonata;0.2\%) and Forsten's Cat snake (Boiga forsteni;0.1\%) are the other venomous species.. Indian Rock Python (Python molurus; 30.1\%) was the commonly rescued non-venomous snake in Kannur. Other non-venomous snakes were Rat snake (Ptyas mucosa; 1.8\%), Common Trinket snake (Coelognathus helena; 1.3\%), Wolf snake (Lycodon aulicus; 0.4\%), Common Kukri (Oligodon arnensis; 0.1\%), Common sand boa (Eryx conicus; 0.3\%) and Red sand boa (Eryx johnii; 0.5\%). Seasonal variations in the number of rescued snakes were discussed. Knowledge of activity pattern of the snake in the district can be used for successful management and conservational plans. Waste management, rodent control, reducing hideout places etc were suggested to decrease the number of snakes entering into house compound. Promoting awareness about the local snake among the public is as important as rescue activities. The increase in rescue call by $40 \%$ in 2013 can be taken as one of the successes of the awareness programs conducted across the district.

Keywords: Snakes, awareness programs, conservation, Kannur District.

\section{INTRODUCTION}

Reptiles are one among the faunas that are adversely affected with anthropogenic development (Gibbons et al. 2000). Habitat deterioration and alterations had made too many reptile species to coexist with the urban environment (McKinney, 2006). The number of snakes had risen in the outskirts of cities of which few snakes were found adapted with human habitations (Purkayastha et al. 2011). This had caused much conflict with humans and eventually snakes get killed when spotted. Malicious killing is one of the factors causing the decline in snake populations (Baruah and Sengupta, 1998). The layman kills snakes due to ignorance regarding environmental conservation, laws regarding the protection of snakes and the significance of snakes in nature (Vyas, 2013).
Conservation of snakes is as important like other species. Rescue activity of snakes was done by the forest department and like-minded people from long time in the district. Rapid Response team was set in 2011 by Kannur Forest Department with an aim to rescue and rehabilitate the wild animals which are in danger. Reptiles are an important component of an ecosystem since it act as both predator and prey for many species (Gibbons et al. 2000). Species richness is one of the essential components of a healthy ecosystem (Schmeller et al., 2008 and Sfenthouraks, 2009). Since ecosystem provides direct services to humans, each species in an ecosystem is having an economic value. But the estimating of this economic value is difficult for many species (Loornis and White, 1996). Poor knowledge among the public regarding the common snakes and many misbelieve was reasons for killing 
the snakes. Also, the amount of effort done by researchers and enthusiasts has not translated to get public support for snakes. Lack of knowledge about snakes population in the area is a drawback for any conservational and management plans. Since population surveys in snakes have many practical difficulties this article is written based on the available source of rescue data of snakes presenting the local diversity and abundance of snakes and commonly encountered snakes in the district.

\section{METHODOLOGY}

To study the local diversity, abundance of the species of snakes, I had requested permission from Rapid Response Team in Kannur Forest department who had regular records of rescues operations made in the district. The collected data included species of snakes and the month wise rescue from 2011-2014, which was then analyzed with the help of 'MS Excel'

\section{RESULTS}

About 16 species of snakes were rescued over a three-year period by the Rapid Response Team under Thaliparamba range of Kannur Forest Division of which venomous snakes (65\%) were more compared to non-venomous snakes (35\%). Commonly encountered venomous snakes were Spectacled Cobra (Naja naja; 44.1\%) and Russell's viper (Daboia russelii; 14.8\%). Other venomous species include Common Krait (Bungarus caeruleus; 3.4\%), King Cobra (Ophiophagus Hannah;2.5\%). Malabar Pit-Viper (Trimeresurus malabaricus), Common Cat Snake (Boiga trigonata) and Forsten's Cat snake (Boiga forsteni;) which are mildly venomous together contributing less than $1 \%$ of the total rescued snake.

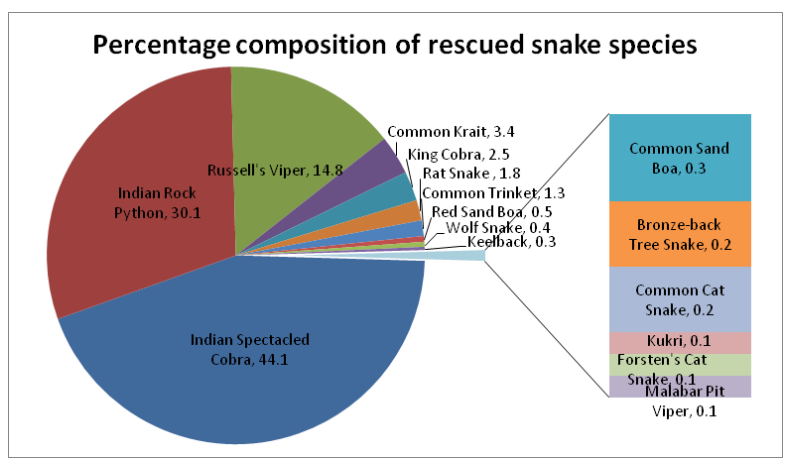

Fig. 1. Percentage composition of rescued snakes from Kannur District (2011 to 2014)

Indian Rock Python (Python molurus; $30.1 \%$ ) was the commonly rescued non-venomous snake in Kannur. Other non-venomous snakes were
Rat snake (Ptyas mucosa; 1.8\%), Common Trinket snake (Coelognathus helena; 1.3\%), Wolf snake (Lycodon aulicus; 0.4\%), Common Kukri (Oligodon arnensis; 0.1\%), Keelbacks (mainly Xenochrophis piscator 0.3\%) Common sand boa (Eryx conicus; $0.3 \%$ ) and Red sand boa (Eryx johnii; 0.5\%). Percentage composition of rescued snakes from 2011 Oct to 2014 Oct is given in figure 1 .

Monthly variation in venomous snakes rescued in Kannur district (Fig. 2) had shown significant variations. Indian Spectacled cobra was highest in number during pre-monsoon - summer time (Feb to Jun) which coincides with the time of reproduction (April- July). Russell' Vipers are mostly nocturnal but in cooler weather it's active during daytime hence most of the snakes were encountered during Nov- Jan and also high encounter of juvenile vipers were found during April to June where they give birth to young ones. Kraits are nocturnal snakes mainly encountered during cooler months (Oct- Jan) of the year. The World's largest venomous snake, King Cobra (36 no.) were rescued in Alakode and Aralam areas of Kannur which are adjacent to Semievergreen forest types highly in the months of Feb April. Pythons were encountered during post monsoon (North-East monsoon) season and peak activity around human beings was seen during OctJan months. Successful awareness had increased the snake rescue calls in the district; there were $40 \%$ increases in rescue calls in 2013 compared to 2012.

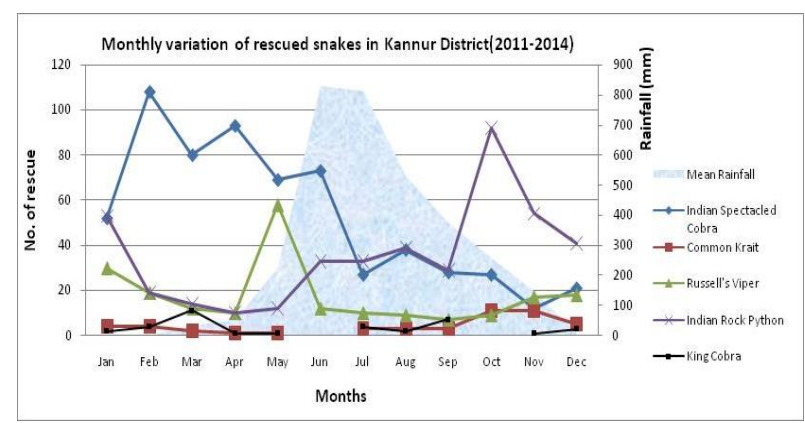

Fig. 2. Monthly variation in top five snakes rescued in Kannur district.

\section{DISCUSSION}

A total of 1427 snakes were rescued in Kannur district of which $65 \%$ were venomous snakes. Higher percentage of venomous snakes may be due to either high population status of these snakes in the area or due to chance that most of the people recognizes venomous snakes and prefer to call for rescue when encountered only venomous. They either avoid non-venomous snakes or kill them. This may be the reason why Rat snakes are recorded 
less $(1.8 \%$ of the total rescue). Top seven species rescued are larger in size, usually terrestrial and shows wide activity time. None of them is exclusively nocturnal. This might be another reason that people don't ignore them when found. Snakes which are recognized for their venom or some myths are likely to be more in rescues. People feel unable to deal with them if they are clearly dangerous or known for some myths for eg Cobra is known for myths and bites. So people don't take much chances and call for rescues even if it is staying far away from the house. Also, Large snakes are cause of fear so even if they are not inside human house people call for their rescues. This includes Python, King Cobra, Cobra and Rat snake etc. Hence this data cannot represent exact population status of snakes in the District but it can be taken as encounter rate of snakes and details such as diversity of snakes, abundance and monthly activity pattern of snakes can be assessed.

Seasonality of snakes rescued reflects the activity pattern of snakes in the district. This information can lead to management and conservational plans to prevent human- snake conflicts. Cobra was found to be common venomous snake encountered in the district. Similar rescue data from Shimoga, Karnataka (Jadageesh et al., 2015) and Amaravati District, Maharashtra (Nande and Deshmukh, 2007) showed a high number of rescued cobras. Cobras were found in more numbers because of the occurrence of their prey species like rat and mice around human habitation. They are solitary, nocturnal and diurnal, but active mainly at dusks and dawns (Khan, 2008; Daniel, 2002). More numbers of rescues were encountered during the summer season. Minimizing rodent population and proper waste management can lead to decrease number of these snakes in the compound. Russell's viper accounts to $14.8 \%$ of the total rescue with 211 individual rescues in the district. These snakes are found mostly in open, grassy/ bushy areas, small jungles, plantation and farmland and known to avoid marshes, swamps and rain forest (Mallow, et al., 2003). It's a nocturnal forager but in cooler conditions it becomes active during the day (Mallow et al., 2003). High numbers of viper were encountered during colder months (Nov- Feb) in the district. Russell's viper have a gestation period of 6 months and produce young during May to July; (Daniels, 2002; Mallow, 2003) hence more Juveniles of Russell's viper were found in the month of May also more bites were recorded in these months (Roshnath unpublished data). Precautions are to be taken during this period while walking out in leaf litters and night hours. Common kraits were rescued less $(3.4 \%)$ in the district and more rescues were encountered during the cooler months (October January) and mostly were found inside houses. Flower pots and other material should be kept away from houses to minimize hideout places for snakes. Care should be taken during working in fields, clearing vegetation or firewood collection. No plants should be planted near to the window and trees branches reaching out to the house should be cut so that snakes won't reach the house

Most of the King Cobra rescued from Kannur came from Aralam and Alakkode regions of Kannur where there is thick forest vegetation nearby. And Most of the king cobras rescued were in newly molted stage (Pers comm. from Riyas Mangad). After molting for every snake, there is a high demand of energy so they forage in search for preys. Ophiophagus hannah is a diurnal predator and feed mainly on snakes and lizards of the genus Varanus. (Cox, 1991; Daniel, 1983). Rat snakes are found near human habitations seeking rodent preys and the King Cobras are after Rat snakes. Eventually, King cobras are encountered near human habitation which causes the conflict. Usually, people seeing King cobra passes the information to Forest Officials and proper actions are taken from the side of the Forest Department. The number of King Cobra rescued (36no) suggests a good population of the species in the District. Nests are usually made in cooler habitat like bamboo thickets inside forest without Human disturbance (Cox, 1991) In India the nesting season for King Cobra extends from April to July (Daniel, 1983) and low number of rescue were observed in these months as these snakes might be in Nesting stage.

A total of 429 individuals were rescued during the period 2011-2014 indicating a high number of pythons in the district. Pythons inhabit a wide range of habitats including wetlands, open forest, scrublands, harsh desert, rainforests, woodlands, grassy marshes, river valleys, mangroves, rocky slopes, and savanna (Murphy and Henderson, 1997; Whitaker 1987) and have a widespread distribution in most parts of India (Whitaker, 1993; Bhupathy, 1995). More activity of python was observed during post-monsoon rains in the district and more juveniles were rescued in the season (pers. Comm. from Riyas M.). Germination of seeds and sprouting of vegetation during monsoon might be used by python hatchlings for shelter during dispersal (Vijayan, 1991). Pet animals and birds, hen cages, and rodents attract pythons near human habitations. People staying near water sources are more to be bothered about pythons 
during rain. Python molurus, Indian rock python is listed in Schedule I of the Indian Wildlife Protection Act 1972, then too about four cases of python poaching for meat and fat was reported in Kannur in 2015 (Pers comm.. Thaliparamb Forester).

The rescued snakes are translocated to the safe and natural environment even though translocation of snakes to its natural habitat is always a question of debate in towns. Translocation is just an immediate mitigation measure to get rid of snakes however other factors such as survival of translocated individual, territoriality, competition pressure etc are not in concern. Better education and awareness to the public should be given for not to capture away some species of snakes those are living outside the house. A decent small distance relocation/shift will help both the community and snakes safe. Most of the snakes are found in human inhabited areas were the prey availability (rats) is more. Proper waste management and rodent control can prevent the snake entering in the house to an extent. Study of sensitivity of herpetofauna towards urban habitat is essential for long-term conservation measures and risk assessment (Raxworthy and Nussbaum, 2000). Increase knowledge among public regarding common snakes would help in conservation of the snakes in the region. Awareness classes are to be taken in areas where there are high populations of snakes (mainly rural areas).

\section{ACKNOWLEDGMENT}

I thank Prabhakaran M.P (Thaliparamb Range Officer) for providing the data. Also thank Riyas Mangad (Animal rescuer, RRT), Jayaprakash and Murali (Forester). I also show gratitude towards Jayaprasad (CCF) and Rajan (DFO) and Kerala Forest Department for their support. I thank Vivek Philip Cyriac and Vivek Sharma for their valuable comments and support.

\section{REFERENCES}

Baruah, M. and S. Sengupta, (1998). Threats to snakes of Assam with special reference to Kamrup District. Zoos' Print. 14: 37-38.

Campden-Main, Simon, (1970). A field guide to the snakes of South Vietnam. 94-95

Cox, Merrel, J., (1991). The snakes of Thailand and their husbandry. Malabar, Florida, Krieger Publishing Company, 34: 301-305.

Daniel, J.C., (1983). The book of Indian reptiles. Bombay, India, Bombay Natural History Society, pp 115-117.
Daniel, J.C., (2002). The Book of Indian Reptiles. Oxford University Press, 137-139.

Das, A., M.V. Nair, M.F. Ahmed and P.K. Sharma, (2008). Distribution of King Cobra (Ophiophagus hannah) in northeastern India with new altitudinal record and notes on its habitat. Tiger Paper 35(4): 1-6.

David, P. and G. Vogel, (1996). The Snakes of Sumatra: An Annotated Checklist and Key with Natural History Notes. Edition Chimaira, Frankfurt-am-Main, Germany, 260pp.

Gibbons, J.W., D.E. Scott, T.J. Ryan, K.A. Buhlmann, T.D. Tuberville, B.C. Metts, J.L. Greene, T. Mills, Y. Leiden, S. Poppy, S. and C.T. Winne, (2000). The global decline of reptiles, déjà vu amphibians. BioScience 50: 655-666.

Hrima, V.L., V.L. Hriatzuala Sailo, Z. Fanai, S. Lalronunga, C.L. Zothansiama and H.T. Lalremsanga, (2014). Nesting ecology of the King Cobra, Ophiophagus hannah, (Reptilia: Squamata: Elapidae) in Aizawl District, Mizoram, India. Issues and Trends of Wildlife Conservation in Northeast India 268- 274.

Jagadeesh, B., Chittaragil and B.B. Hosetti, (2015). Spatio-Temporal Dynamics of Snakes in a human-altered landscape in semi-Malnad (MidWestern Ghats) Region of Shimoga, Karnataka ZOO's PRINT, XX: 14-18

Khan, M.M.H., (2008). Protected Areas of Bangladesh - A Guide to Wildlife. Nishorgo Program, Bangladesh Forest Department, Dhaka, Bangladesh, 244p.

Leviton, A.E., G.O.U. Wogan, M.S. Koo, G.R. Zug, R.S. Lucas and J.V. Vindum, (2003). The dangerously venomous snakes of Myanmar. Illustrated checklist with keys. Proc. California Acad. Sci. 54(2): 407-462.

Loomis, J.B. and D.S. White, (1996). Economic value of increase rare and endangered fish. Fisheries 21:6-10

Loveridge, Arthur, (1946). Reptiles of the Pacific World. New York Macmillan Company, 146147.

Mallow, D., D. Ludwig and G. Nilson, (2003). True Vipers. Natural History and Toxinology of Old World Vipers. Krieger Publishing Company, Malabar, Florida.

McKinney, M.L., (2006). Urbanization as a major cause of biotic homogenization. Biol. Cons. 127: 247-260. 
Murphy, J.R. and R.W. Henderson, (1997). Tales of giant snakes: A natural historical history of anacondas and pythons. Krieger Publishing Co. FL.

Nande, R. and S. Deshmukh, (2007). Snakes of Amravati District including Melghat, Maharashtra with important record of Indian Egg eater MOntane Trinket and Indian Smooth Snake, Zoo's Print Journal 22(12): 2920- 2924

Purkayastha, J., M. Das and S. Sengupta, (2011). Urban herpetofauna: a case study in Guwahati City of Assam, India. Herpetology Notes 4: 195202

Raxworthy, C.J. and R.A. Nussbaum, (2000): Extinction and extinction vulnerability of amphibians and reptiles in Madagascar. Amph. Reptile Cons. 2: 15-23.

Schmeller. D.S., B. Bauch, B. Gruber, R. Juskaitis, E. Buddry, V. Babij, K. Lanno, M. Sammul, Z. Varga, and K. Henele, (2008). Determining conservation priorities in the region with multiple political jurisdictions. Biodiv. Cons. 17:3623-3630

Schmidt, Karl, P. and Robert F. Inger, (1957). Living Reptiles of the World. Garden City, NY, Hanover House, 236-237
Selich, H. and W. Kästle (eds), (2002). Amphibians and Reptiles of Nepal. Gantner, A.R.G., V.G. Verlag and Ruggell (distributed by Koeltz, Koenigstein, Germany), 1201pp, 127pls. (including $374 \mathrm{col}$. figs).

Sfenthourakis, S. (2009). Habitat diversity, ecological requirements of species and the small island effect. Diversity Distrib.15: 131-140

Vijayan, V.S. (1991). Keoladeo National Park Ecology Study. Final Report (1980-1990). Mumbai: Bombay Natural History Society.

Vyas, R., (2013). Snake diversity and voluntary rescue practice in the cities of Gujarat State, India: an evaluation. Reptilerap 28-39.

Whitaker, R. and A. Captain, (2004). Snakes of India, The Field Guide. Draco Books, Chennai, Xiv+481pp.

Whitaker, R., (1987). Common Indian snakes - A field guide. The Macmillan Company of India Limited, pp. 6-9.

Zug, George R., (1993). Herpetology, an Introductory Biology of Amphibians and Reptiles. Academic Press, Inc. pp 181-182. 